\title{
The Based on Innovation credits to the Cultivation of Innovative Ability of Undergraduates
}

\author{
Jing Zhang ${ }^{\mathrm{a}}$ and $\mathrm{Na} \mathrm{Li}$ \\ School of Art and Design, Xi'an University of Technology, ShanXi province, 710054, China \\ a756225884@qq.com, b814610426@qq.com
}

Keywords: credit system; innovation credit; innovation ability; innovative education

\begin{abstract}
It is based on the innovation credits to analyze credit system and construction, which are conducive to the cultivation of innovation and entrepreneurship ability, and consummate the innovation practice curriculum system, and formulate the innovation credit incentive policy, and encourage students to participate in the internal and external innovation training, in order to improve the ability of college students to innovate and start their own business.
\end{abstract}

\section{Introduction}

Innovative credits are full-time undergraduate students in accordance with their own expertise and hobbies engaged in beyond the professional teaching plan requirements, in scientific research and practiced results, learning and competition results, expertise and skills or certificates and other activities and achieved high scores. The credits received by the School of Certified Students, and the credits awarded after accreditation. Innovation credits are the establishment of credit credits for college students is the extension and perfection of the credit system, which is the demand for higher education to adapt to the market economy, and the development of undergraduate practice teaching system is an important part.

\section{The importance and function of innovation credits}

In order to meet the demand of high-quality talents for the development of the times and to create an atmosphere in which students actively participate in scientific practice in extracurricular activities, enhance students' sense of innovation and innovative credits proposed by institutions of higher learning on the basis of credit system, this not only enriches the content of innovative education, To a certain extent, it also follows the law of cultivation of innovative talents, opens up new ways for perfecting the credit system reform and advances the reform of higher education in depth. In its Decision on Deepening Education Reform and Promoting Quality Education in an All-round Way, the Ministry of Education explicitly stipulated that higher education should attach importance to cultivating the innovative ability, practical ability and entrepreneurial spirit of undergraduates and generally raise their humane quality and scientific quality. Implementation is conducive to students 'comprehensive knowledge of learning and personal interest training to promote science and technology activities carried out by college students, thereby enhancing students' ability to innovate and sense of innovation, and cultivate a highly innovative and comprehensive development of high-quality personnel.

\subsection{To stimulate the cultivation of student personality}

Each student has different cognitive characteristics, different interests and hobbies, different desire requirements, different value orientation, the establishment of credit in the credit system platform for the creation of credits, students can according to their own interests and expertise, initiative, flexibility and choice of innovation Content and elective courses, students can not only mobilize the initiative and enthusiasm, but also respect the personality development of students, so that their own ability to give full play to their ability. 


\subsection{To stimulate the competitive training of students}

The establishment of innovative credits can introduce the competition mechanism into teaching so that undergraduates can reach the project or competition as soon as possible so as to help students set goals and guide them to consciously and selectively participate in the corresponding quality development and innovation so as to make students innovate Ability to adapt to a wide range of societies, to accelerate innovation and enhance the ability to learn and work in the future. On the other hand, under the requirements of innovative credits, teachers can also be encouraged to participate in the competition. Teaching content and teaching methods are continuously updated so that the enthusiasm of teaching and learning can be further raised.

\subsection{Promote the reform of credit system needs}

At present, the actual implementation of credit system in various colleges and universities is the form of academic credit system, not a pure credit system. Therefore, setting up credits to improve credit system is conducive to finding a new starting point for the reform of credit system, embodying the multi-layered and people-oriented connotation of credit system, followed the training of talents and publicizing students' personality and specialty. Therefore, to say that innovative credits is an effective way to cultivate students' innovative spirit and obtain good talents training benefits.

\section{The Present Situation of Innovation Credits in the Universities}

\subsection{Innovative credit system is not perfect, leading to innovation credits is out of touch}

The construction of innovative credit system has a comprehensive and systematic characteristics. At present, although the local colleges and universities have innovative credit implementation program, the program covers the whole school students, but most of the implementation for the program are too simple or rough, for different disciplines, various professions, departments do not have specific implementation requirements. The purpose of innovation credits is to encourage students to actively participate in various innovative practice activities, including various academic competitions, scientific activities, social practice activities, etc.. However, a large number of local colleges and universities concerning how to regulate student activities lacking the corresponding system of regulations, leading to teachers or Students only can follow their own subjective understanding of the activities of the guidance or participation, resulting in chaotic disorder, and the implementation of innovative credit process will appear fault or disjointed behavior.

\subsection{The innovative credits is out of touch with practice teaching}

The implementation of innovative credit is an effective means of educating people in colleges and universities, and it is an effective platform for college students to improve their practical skills. In the student's learning process, only the combination of theory and practice, in order to deepen the theoretical theory, students should not only learn the theory, but also practice, but also to the theory of practice, the implementation of innovative credits is also reflected Theory and practice of combining the principles. However, in the actual operation of local colleges and universities, the implementation of innovative credits is independent of practical teaching, classroom teaching system, the teacher's theory of teaching and students of innovative practice separated, the students have the theoretical knowledge to guide the practice of practice, leading to the students' application of innovation capability and acquisition of creative credits.

\subsection{Lack of practice base, it is difficult to innovate}

The implementation of innovative activities in college students requires the combination of many elements, the implementation of innovative practice activities in addition to the conditions of their own students, but also need to create conditions for schools, including school, outside the various types of resources to provide. At present, colleges and universities encourage students to participate 
in various innovative practice activities, for students' activities through the record results or other credit incentives to show, but the school do not provide students with sufficient condition to complete this work, practice equipment, practice site Lack of need to meet the needs of students' innovative activities.

\section{Reform measures}

\subsection{Build an innovation credit system}

In order to make innovation credits into art professionals to cultivate innovative talents and strengthen the ability of students to innovate the breakthrough ability, should be innovative credits as an opportunity, according to the different grades should be put forward different in-school innovation credits and extracurricular innovation credit requirements, and into a certain score. In order to play the role of innovative credit on the cultivation of talent. At the same time, in accordance with the needs of the arts profession to encourage students to learn the cross and diversity, to develop innovative ability of the plan. To develop the appropriate supporting system to achieve the effectiveness of innovative credit system, and increase the practical skills of the course training, appropriate to improve the credit from 2 to 4 points, so that students for the back of graduation, employment and lay a solid foundation for innovation.

\subsection{Optimize the curriculum system}

The implementation of innovative credits first requires the innovation activities of colleges and universities to be separated from the simple theory of teaching and form a certain system. Because the strengthening of students' innovative quality is not only reflected in the solid foundation of students' theoretical foundation and social practice ability, but also embodies the students' ability to integrate between theory and practice. In order to make innovation credits a breakthrough in cultivating applied talents and strengthening students' ability of innovation and practice, we should highlight the general education curriculum and optimize the curriculum system in the development of "thick foundation and wide caliber" Based on the training objectives, the establishment of mastery, closely with the organic link of the curriculum system, set up different curriculum modules to meet the needs of the development of students ' personality, in order to meet the needs of the development of students' personality, to strengthen the application of the principle, In order to play innovative credit on the cultivation of undergraduate talent to promote the role.

\section{3 innovative practice courses}

Innovative practice curriculum is to cultivate students' innovative spirit and scientific research ability of elective courses. At the end of each semester, you should set up innovative practice courses to ensure that the basic teaching requirements of the professional, in full consideration of different professional and different personnel training based on the positioning, to provide students with adequate personalized professional curriculum resources, so that both Each student on the innovative practice of personalized courses, but also to expand and extend the students' ability to research and create inventive ability.

\subsection{Improve the incentive mechanism of innovative credit}

The essence of the innovation credit is the materialization affirmation of the quantitative assessment and innovation ability of the innovation achievement of college students. Each institution of higher learning should formulate the methods of implementing innovative credit credits and corresponding incentive policies in accordance with the principle of combining rigid regulations with independent choice and incorporate these policies into the undergraduate teaching plan. Excellent innovation to students awarded qualified and excellent certificate to achieve a higher level of innovative students to give a certain reward, and as a recommended graduate students, one of the evaluation criteria for evaluation, or you can use innovative credits to replace a certain percentage of elective courses The these measures will inspire the enthusiasm of the students to 
make them consciously take the initiative to participate in the process of innovation education, so as to improve the effectiveness of innovative education.

\section{Conclusion}

Innovation is a soul of national progress, institutions of higher learning as a culture of senior art talent hall, innovative credit practice innovation, promote the credit system optimization, so that the quality of education has been significantly improved, educational resources are optimized, school characteristics are highlighted, highlight the comprehensive development of comprehensive personnel training model.

\section{Acknowledgement}

This research was financially supported by Department of Education of Shaanxi Province and Department of Culture of Shaanxi Provice.(16JK1531,SY2016047)

\section{References}

[1] Dong Fengli, An Junxue. Innovative credits: to improve the credit system reform of the new exploration [J]. Higher Agricultural Education, 2007,4: 61

[2] Ministry of Education. On the further strengthening of undergraduate teaching in colleges and universities a number of opinions [Z].

[3] Guo Guangchu. Under the credit system under the conditions of the traditional school management system reform [J] .Heilongjiang Higher Education Research, 2000, (1): 33-35.

[4] Lin Quanye, Duan Zu'an, Liang Hua.Study on Laboratory Management System and Operation Mechanism in Colleges and Universities [J]. Journal of Shandong Agriculture Education, 2008 (4): 54-58.

[5] Deng Shurong. Local colleges and universities to implement the status quo of innovation credits and countermeasures - A case study of local colleges and universities in Guangdong Province [J]. Huizhou University, 2013,08: 121-125. 